Ülevaade. Kirjeldan artiklis modaalverbide saama ja võima konstruktsioonide arengut kirjalikus B1-ja B2-taseme õppijakeeles. Vaatlen saama- ja võima-konstruktsioonide esinemissagedust, täpsust ning morfoloogilist, süntaktilist ja funktsionaalset jaotuvust kummalgi tasemel, jälgin konstruktsioonide arenguradasid õppijakeeles ning otsin B1- ja B2-taset eristavaid indikaatoreid.

Uurimuse tulemused näitavad, et nii saama- kui ka võimakonstruktsioonid arenevad B1-tasemelt B2-tasemele liikudes õppijakeele konstruktsioonide üldiste seaduspärasuste järgi. Verbi saama konstruktsioonide areng on sujuvam, verbi võima konstruktsioonide arengus toimub aga märgatav arenguhüpe. Võima-konstruktsioonid on B2-tasemel neli korda sagedamad kui B1-tasemel, väheneb nende sõltuvus tekstitüübist, kasvab eri morfoloogiliste vormide arv ning konstruktsioonid muutuvad süntaktiliselt ja funktsionaalselt mitmekesisemaks. Seega võib võima-konstruktsioonide arengut pidada B1-ja B2-taset eristavaks indikaatoriks.*

Võtmesõnad: teine keel, keele omandamine, sagedus, täpsus, jaotuvus, eesti keel

\title{
1. Sissejuhatus
}

Kui inimene omandab keelt (olgu esimest või teist), siis tema oskus seda kasutada areneb aja jooksul. Areng toimub nii funktsionaalselt (isik suudab täita rohkem erinevaid suhtlusülesandeid) kui ka lingvistiliselt. Teise keele oskuse määramine põhineb tänapäeva Euroopas funktsionaalse arengutaseme hindamisel ja seda tehakse "Euroopa keeleõppe raamdokumendi" (CEFR 2007) järgi. Selles mahukas käsiraamatus on esitatud kuue keeleoskustaseme (A1 ja A2 ehk algaja keeleoskaja;

* Artikli valmimist on toetanud riikliku programmi “Eesti keel ja kultuurimälu II" projekt EKKM 15-419 
B1 ja B2 ehk iseseisev keelekasutaja; $\mathrm{C} 1 \mathrm{ja} \mathrm{C} 2$ ehk vilunud keelevaldaja) funktsionaalsed kirjeldused. Kirjeldused kehtivad mistahes keele kohta ning neis on loetletud oskused, mida isik vastaval tasemel teha suudab. Vaatamata kirjelduste põhjalikkusele on küllalt sageli raske mõista, mida mingi oskus täpsemalt tähendab, näiteks mille poolest erinevad määratlused "oskab kirjutada lühikesi lihtsaid sõnumeid, mis puudutavad talle vajalikke asju" (A2) ja "oskab kirjutada sõnumit, mis edastab lihtsat hädavajalikku teavet sõpradele, teenindajatele, õpetajatele jt, kellega ta igapäevaelus kokku puutub; suudab edastada kõige olulisemat" (B1) (CEFR 2007: 101). Raamdokumendi kasutajatele oleksid abiks lingvistilised kirjeldused, mis täpsustaksid, millised keelestruktuurid ja milline sõnavara on eri tasemetele tüüpilised. Lingvistilisi kirjeldusi ei saa nende spetsiifilisuse tõttu aga koostada kõigi keelte jaoks ühiselt, need tuleb luua iga keele ekspertidel eraldi.

Teise keele lingvistilist arengut uurides mõõdetakse üldjuhul kvantitatiivseid muutusi CAF-triaadi dimensioonides ( $C$ - keerukus, ingl complexity; $A$ - täpsus, ingl accuracy; $F$ - sujuvus, ingl fluency; vt Housen jt 2012). Keerukust mõõdetakse traditsiooniliselt selliste näitajatega nagu lausete pikkus, kõrvallausete hulk pealause kohta jne. Täpsuse hindamisel vaadeldakse enamasti vigade arvu suhet keeleühikute koguarvuga, näiteks saja sõna kohta. Sujuvuse arengu näitajateks on produtseeritud tekstiühikute hulk mingis ajaühikus, katkestuste arv ja pikkus, korduste hulk jne, mida jälgitakse peamiselt suulises tekstis. Vaatamata CAF-triaadi dimensioonide mõõtmisel saadud olulisele infole, jääb sellest keelelise arengu tasemepõhiseks mõistmiseks siiski väheks.

Võrgustikku SLATE (Second Language Acquisition and Testing in Europe) koondunud teadlased on aga keskendunud just eri keelte oskustasemete keeleliste tunnuste leidmisele ning mitme keele kohta on tasemepõhised lingvistilised kirjeldused ka loodud või loomisel. Tuntuim neist on Cambridge’i õppijakeele korpuse uuringute põhjal loodud inglise keele lingvistiline kirjeldus "English Profile", milles kirjeldatakse igale keeleoskustasemele iseloomulikku sõnavara ja struktuure ning nende tüüpilisi kasutusfunktsioone. Eesti õppijakeele uuringutel põhinevad keeleoskustasemete kirjeldused seni puuduvad.

Viimasel ajal on teise keele omandamise uurimises kerkinud esile uus suund: konstruktsioonide arengu jälgimine (Eskildsen 2008, Martin jt 2010). See lähenemine põhineb arusaamal, et keel ei koosne eraldi leksikast ja grammatikast, vaid konstruktsioonidest, milles sõnad ja grammatika on omavahel lahutamatult põimunud ning seega tähendab keeleoskuse omandamine konstruktsioonide omandamist. Teise keele konstruktsioonide arengut on uuritud nii indiviidide (Eskildsen 2008) kui ka suurte gruppide kaupa tasemete ning CAF-triaadi dimensioonidega seotult (nt Martin jt 2010, Seilonen 2013, Reiman 2011, Mustonen 2015). Tulemused näitavad, et konstruktsioonidel on oma arenemise seaduspärasused ja arengurajad, mida mõjutab pigem keele kasutamine kui õpetatavad reeglid.

Varasemates uuringutes olen vaadelnud konstruktsioonide arengut eesti õppijakeeles. Olen kirjeldanud verbi tahtma konstruktsioone (Kitsnik 2014) ning tingiva kõneviisi konstruktsioone (Kitsnik 2015) B1- ja B2-taseme kirjalikus õppijakeeles. Käesolevas artiklis esitan modaalverbide saama ja võima konstruktsioonide uuringu tulemused ning selle põhjal tehtud järeldused, mis aitavad eesti õppijakeele arengu põhimõtteid paremini mõista. Artikkel koosneb kuuest osast. Pärast esimest, sissejuhatavat osa annan teises osas lühikese teoreetilise ülevaate konstruktsioonidest 
ja nende arengu seaduspärasustest. Kolmandas osas selgitan uurimisteemat ja esitan uurimisküsimused ning neljandas osas kirjeldan uurimismaterjali ja uurimismeetodit. Viiendas osas esitan uurimistulemused ning kuuendas osas kokkuvõtte.

\section{Keelekonstruktsioonid ja nende areng}

Keelekonstruktsiooni mõiste pärineb konstruktsioonigrammatikast (Goldberg 1995, 2003), mille järgi koosnevad kõik keeled konstruktsioonidest - ühikutest, milles sõnad ja grammatika on omavahel põimunud. Konstruktsioonid esinevad eri tasanditel (nt morfeemi, sõna, fraasi, idioomi, lause tasandil) ning on eri pikkuse ja abstraktsusega. Konstruktsioonis moodustavad keelelise ühiku vorm, tähendus ja suhtlusfunktsioon ühtse terviku. Keelekasutaja mälus paiknevad konstruktsioonid keeruka mitmekihilise võrgustikuna, mille osad on omavahel eri vahekordades (sünonüümia, antonüümia, alluvus jm) ning võimaldavad eri määral varieerumist ja laienemist. Kui inimene keelt kasutab, ei moodusta ta iga väljendusüksust algusest peale uuesti, vaid paneb selle kokku mälus olevatest konstruktsioonidest, mida teatud määral produktiivselt täiendab. Keelt kasutades on konstruktsioonid omavahel põimunud, üks võib olla teise osa.

Seda, kuidas konstruktsioonid keelde tekivad ja arenevad, seletatakse kasutuspõhiste teooriate (ingl usage-based theories) kaudu. Nende teooriate hulka kuuluvad kognitiivne grammatika (Langacker 2008), kaose-komplekssuse teooria (Larsen-Freeman 1997), vestlusanalüüs (Firth, Wagner 1997), sageduspõhine teooria (Ellis 2002), dünaamiliste süsteemide teooria (Verspoor, Behrens 2011). Kõiki neid teooriaid ühendab arusaam, et keeleomandaja konstruktsioonid tekivad ja arenevad elu jooksul teiste inimestega suhtlemise käigus. Isik saab autentsest keelekeskkonnast suuremahulise sisendi, milles keeleline materjal esineb suhtlusolukordadega seotult ega ole järjestatud raskuse järgi. Keeleomandaja kuuleb-näeb väga palju erisuguseid n-ö keeletükke (ingl chunks) ning hakkab neid konteksti toel järk-järgult märkama, mõistma ja meelde jätma. See protsess toimub inimesel keele sees viibides üldiste kognitiivsete võimete ja varasema kogemuse abil nii teadvustatult kui ka teadvustamatult. Seejärel hakkab keeleomandaja proovima neid tükke ka ise kasutada ning ennast väljendades ja sellele vastust saades omandab järk-järgult keeleliste väljenduste vormi, tähenduse ja suhtlusfunktsiooni komplekte. Kogemuse üldistamise abil tekib tal alateadlik arusaam konstruktsiooni olemusest. Kui mingi konstruktsiooni mõiste on kujunenud, suudab keeleomandaja analoogia põhjal ka ise samalaadseid konstruktsioone produtseerida.

Konstruktsioonide märkamine sõltub paljudest teguritest: konstruktsiooni esinemissagedusest sisendkeeles, konstruktsiooni esilduvusest, konstruktsiooni vormi olulisusest sõnumi mõistmisel jm. Keele produtseerimine algab prototüüpsetest konstruktsioonidest. Need on seotud kõige sagedasemate sõnade ja vormidega keeles ning keeleomandaja märkab, identifitseerib ja jätab need meelde esimestena. Prototüüpsed konstruktsioonid murravad kasutustee lahti ja seejärel hakkavad sama tüüpi konstruktsioonid morfoloogiliselt, leksikaalselt, süntaktiliselt ja funktsionaalselt laienema. Eri suundades laienemine ei toimu kõigi konstruktsioonide ega ka sama konstruktsiooni puhul samas mahus ega sama kiirusega. (Ellis 2002) 
Teise keele õppija konstruktsioonid ei ole kohe stabiilsed, vaid võivad rohkemal või vähemal määral sihtkeelest erineda. Aja jooksul muutub õppijakeel sihtkeelele sarnasemaks, kuid see ei ole ühtlaselt tõusvas joones kulgev protsess. Keeleomandaja peab korraga toime tulema paljude eri konstruktsioonidega (sh esimese keele konstruktsioonidega), mille vahel käib pidev võitlus oma koha eest (MacWhinney 2004), keeleomandamine sisaldab nii tõuse kui ka langusi. Ideaaljuhul jõuab teise keele kasutaja lõpuks olukorrani, kus tema keeles on suhteliselt stabiilsed konstruktsioonid, mis sarnanevad üldjoontes emakeelse sihtkeelekõneleja omadele. Et keel on aga kompleksne, kohanduv ja dünaamiline süsteem, ei lõpe tema õppimine kunagi. "Ei ole nii, et inimene õpib midagi selgeks ja siis kasutab seda. Ei ole ka nii, et ta kasutab midagi ja siis õpib selle selgeks. Tegelikult inimene õpib samal ajal, kui keelt kasutab - need kaks protsessi on lahutamatud." (Larsen-Freeman 2007: 783)

Teise keele konstruktsioonide teket on uuritud nii indiviidi tasandil (Eskildsen 2008) kui ka raamdokumendi tasemete kaupa üldistatult (soome uurijad projektides Cefling ja Topling). Soomlased on seejuures ühendanud konstruktsioonide arengu jälgimise ja CAF-triaadi dimensioonide mõõtmise. Selleks on nad välja töötanud mudeli DEMfad (Martin jt 2010), milles $D$ (ingl domain) tähendab uuritavat konstruktsiooni, $E$ (emergency) konstruktsiooni ilmumist keelde ja $M$ (mastery) konstruktsiooni valdamist. Seega algab konstruktsiooni arengurada ilmumisest $(E)$ ja lõpeb valdamisega $(M)$. Arengu uurimiseks analüüsitakse konstruktsiooni esinemissagedust $f$ (frequency, võetud kasutusele sujuvuse mõõtmiseks), konstruktsiooni kasutustäpsust $a$ (accuracy) ning konstruktsiooni leksikaalset, vormilist ja funktsionaalset jaotuvust $d$ (distribution, võetud kasutusele keerukuse mõõtmiseks).

Soomlaste uurimused toetavad seisukohta, et konstruktsioonide arengu põhiolemus on ühesugune. Eri konstruktsioonid ilmuvad keelde eri ajal, kuid paljud juba keeleomandamise alguses. Konstruktsioon tekib keelde mõne sagedase sõna ja vormiga ning seda kasutatakse algul valmisüksusena. Teatud aja järel hakkavad keeleomandajad analoogiale tuginedes konstruktsiooni ise produtseerima, mis toob kaasa selle sageduse tõusu ning leksikaalse, vormilise ja funktsionaalse laienemise. Mida rikkalikum on keeleomandajate kokkupuude autentse keelega, seda hoogsamalt selline laienemine toimub (Mustonen 2015). Eri tüüpi laienemine ei pea toimuma paralleelselt, vaid võib aset leida eri keeleoskustasemetel. Aktiivne iseseisev produtseerimine toob kaasa ka keelelise täpsuse languse, mis aga teatud aja järel pidurdub ja konstruktsioonid muutuvad järjest korrektsemaks (Martin jt 2010).

Kokkuvõttes võib öelda, et keeletaseme indikaatorid võivad olla nii kvantitatiivsed kui ka kvalitatiivsed. Indikaatoriks võib olla nii mingi konstruktsiooni esinemine kui ka puudumine, esinemissageduse tõus või langus, ebatäpsuste esinemine või puudumine, ebatäpsuste liigid, konstruktsiooni leksikaalne, vormiline ja funktsionaalne keerukus. 


\section{Uurimisteema ja uurimisküsimused}

Artikli aluseks olnud uurimuses jätkasin B1- ja B2-taseme kirjaliku õppijakeele konstruktsioonide võrdlemist, tasemete lingvistiliste indikaatorite otsimist ning konstruktsioonide arenguradade jälgimist, keskendudes modaalverbide saama ja võima konstruktsioonidele. Konstruktsioonina käsitlen siin modaalverbi saama või võima ühendit $d a$-infinitiivi ja selle laienditega, mis kokku moodustab tähendusliku terviku. Paaril korral esinevad saama ja võima ka ilma $d a$-infinitiivita, ka need juhud on arvestatud konstruktsioonide hulka. Otsin vastuseid järgmistele uurimisküsimustele.

1. Milline on saama- ja võima-konstruktsioonide esinemissagedus, kasutustäpsus, morfoloogiline, süntaktiline ja funktsionaalne jaotuvus B1- ja B2-taseme kirjalikus õppijakeeles?

2. Millised on saama- ja võima-konstruktsioonide arengurajad ning B1- ja B2-taset eristavad indikaatorid?

Verbid saama ja võima kuuluvad eesti keele tuumverbide hulka, mille määratlemise kriteeriumid on üldmõistelisus, polüseemsus, grammatiline funktsioon, sage esinemine keeles, varane omandamine jm (Tragel 2003). Nii saama kui ka võima esinevad kõigis morfoloogilistes vormides. Süntaktiliselt on tavalisimad ühendid $d a$-infinitiiviga.

Saama ja võima kuuluvad eesti kolme levinuima modaalverbi hulka. Kummagi verbi abil väljendatakse kõiki nelja üldist modaaltähendust: episteemilist, dünaamilist, deontilist ja mittedeontilist (Erelt 2013: 117-119). Uurimuses olen saama ja võima suhtlusfunktsioonide eristamisel aluseks võtnud "Eesti keele seletava sõnaraamatu" (EKSS) liigituse.

Modaalverbi saama suhtlusfunktsioonid olen jaganud järgmiselt: 1) võime (osalejasisene dünaamiline modaalsus; subjekt on võimeline midagi tegema, sest tal on selleks oskused, võimed, jõud vm sisemised omadused, nt ma saan kõvemini ka rääkida, kui vaja on); 2) võimalus (osalejaväline mittedeontiline modaalsus; subjektil on võimalus midagi teha, sest on olemas selleks vajalikud välised ressursid või tingimused, nt sa saad ju minuga kinno tulla, sul on õhtu vaba); 3) võimalikkus (osalejaväline mittedeontiline modaalsus: on üldiselt võimalik midagi teha, sest selleks on olemas vastavad ressursid või tingimused; lause on tavaliselt üldisikuline, nt sellisel teel saab sõita suure kïrusega); 4) lubatus (osalejaväline deontiline modaalsus; midagi on lubatud või keelatud teha, nt ma ei saa sinu eest allkirja anda).

Verbi võima funktsioonid on 1) lubatus, võimalikkus (osalejaväline deontiline modaalsus; kellelgi on võimalus, õigus või luba midagi teha, nt president võibjätta seaduse kinnitamata); 2) võime (osalejasisene dünaamiline modaalsus; miski on võimalik tegija võimete, suutlikkuse tõttu, nt hunt võib korraga ära süüa kümme kilo liha); 3) võimalikkus, tõenäolisus (episteemiline modaalsus; sündmus või olukord on võimalik, mõeldav või tõenäoline kõnelejast sõltumatute asjaolude tõttu, nt võib juhtuda, et loeng jääb ära); 4) põhjendatus (osalejaväline mittedeontiline modaalsus: millekski on olukorrast tingitult põhjust, miski on põhjendatud, nt sellist nähtust võib pidada väga haruldaseks); 5) kõneleja tahe (dünaamiline modaalsus; verb on tavaliselt ainsuse esimeses pöördes, nt ma võin suitsetamise päevapealt mahajätta); 6) soovitatavus, mõistlikkus kõneleja arvates (osalejaväline 
mittedeontiline modaalsus, verb on harilikult tingivas kõneviisis, nt võiksime ehk parem uиe külmkapi osta).

Võrreldes verbiga saama on verbil võima suhtlusfunktsioone rohkem ning mitmed tähendused tunduvad abstraktsemad (grammatilisemad), mis muudab võima omandamise eeldatavalt keerukamaks. Esimese keele uurimused on näidanud, et ka lapsekeelde ilmub võima hiljem kui saama (Tragel 2003: 23).

\section{Uurimismaterjal ja -meetod}

Uurimismaterjaliks on täiskasvanute eesti keele riikliku B1- ja B2-taseme eksami kirjutamisosa tekstid, mis on kättesaadavad Tallinna Ülikooli eesti vahekeele korpuses (EVKK). Uurimistöö tarbeks olen koostanud B1-taseme alamkorpuse (24 624 sõnet) ja B2-taseme alamkorpuse (21 783 sõnet). B1-taseme alamkorpuses on kahte tüüpi tekste: kiri/teade (pikkus umbes 50 sõna) ja jutustav tekst etteantud teemal (pikkus umbes 100 sõna). B2-taseme alamkorpuses on kolme tüüpi tekstid: poolametlik kiri (pikkus umbes 140 sõna), arutlev essee (pikkus umbes 180 sõna) ja lähteandmete põhjal koostatud kokkuvõte (pikkus umbes 180 sõna). Alamkorpustesse olen kogunud tekstid, mille autorid on saanud eksami kirjutamisosa eest 60-95\% maksimaalsest hindest. Alla 60\% tulemusega tööd ei ole vastava taseme kohased. Üle $95 \%$ tööd jäid uurimisest välja, sest nende autorid võivad olla vastavast tasemest tunduvalt tugevamad (nt vale taseme eksamile sattunud või koguni eestlased). Kuigi B1- ja B2-taseme tekstitüübid on mõnevõrra erinevad, sobivad need keelestruktuuride võrdlevaks uuringuks. Tekstitüüp on üks keeleoskustaseme tunnusjoontest (CEFR 2007: 97-105), isik peab valdama taseme tekstitüüpideks vajalikke konstruktsioone. Uurin tasemete üldisi keelelisi seaduspärasusi ega arvesta seetõttu tekstide autorite emakeelt, haridust ega muu taustainfot, mis pole ka kättesaadav.

Uurimismeetodiks on korpusest tulenev lähenemine (corpus-driven approach), mis tähendab korpusainestiku analüüsi ilma eelneva hüpoteesita. Uurimismeetod on ühelt poolt kvantitatiivne: jälgin konstruktsioonide esinemissagedust ja eri konstruktsioonide osakaalu. Teiselt poolt on uurimismeetod kvalitatiivne: analüüsin konstruktsioonide sisu ja täpsust semantiliselt ning kontekstipõhiselt. Alustasin tuumverbide rühmast. Kõigepealt moodustasin kummastki korpusest programmi Simple Concordancer kasutades verbivormide sagedusloendi. Seejärel leidsin loendist tuumverbide vormid ning iga tuumverbi esinemissagedused kummaski korpuses. Võrreldes tuumverbide esinemist, selgus modaalverbide saama ja võima sageduste suur erinevus, mille tõttu otsustasin neid verbe sisaldavaid konstruktsioone lähemalt uurida. Leidsin modaalverbe saama ja võima sisaldavad konstruktsioonid. Seejärel analüüsisin kummagi verbi konstruktsioonide esinemissagedust (jaotis 5.1), täpsust (5.2), jaotuvust morfoloogiliselt (5.3.1), süntaktiliselt (5.3.2) ja funktsionaalselt (5.3.3) ning võrdlesin kõiki B1- ja B2-taseme uurimistulemusi. 


\section{Tulemused}

\subsection{Modaalverbe saama ja vôima sisaldavate konstruktsioonide esinemissagedus}

Mudeli DEMfad alusel olen kõigepealt vaadelnud modaalverbe saama ja võima sisaldavate konstruktsioonide esinemissagedust $(f)$. Selle leidmiseks on loetud kokku vastavate konstruktsioonide arv ja seejärel leitud konstruktsiooni esinemissagedus 1000 sõne kohta. Lisaks üldisele esinemissagedusele on vaadeldud ka konstruktsioonide esinemist tekstitüüpide kaupa (5.1.2). Esitatud on nii täpsete kui ka ebatäpsete konstruktsioonide esinemissagedused ( $a$ ). Täpseks on peetud konstruktsioone, mis uurimuse autori kui emakeelekõneleja hinnangul on nii vormiliselt korrektsed kui ka sisuliselt mittehäirivad. Seejuures on vaadeldud verbide saama ja võima ühendeid ühe peamise nende juurde grammatiliselt ja sisuliselt kuuluva sõnaga.

\subsubsection{Esinemissagedus}

Kirjeldan siin saama- ja võima-konstruktsioonide esinemissagedust, kusjuures arvesse lähevad nii täpsed kui ka ebatäpsed konstruktsioonid (mudelis DEMfad näitajad $f$ ja $a$ ). Tabelis 1 on esitatud konstruktsioonide esinemissagedus ja täpsete ning ebatäpsete juhtude osakaal.

Tabel 1. Saama- ja võima-konstruktsioonide esinemissagedus (absoluutarvud ja osakaalud vastava taseme konstruktsioonidest)

\begin{tabular}{|l|c|c|c|c|}
\hline Näitaja & saama B1 & saama B2 & võima B1 & võima B2 \\
\hline Koguarv & 91 & 133 & 36 & 127 \\
\hline Koguarv 1000 sõne kohta & 3,7 & 6,1 & 1,5 & 5,8 \\
\hline Täpsete konstruktsioonide arv & 72 & 118 & 27 & 111 \\
\hline Täpsete konstruktsioonide arv 1000 sõne kohta & 2,9 & 5,4 & 1,1 & 5,1 \\
\hline Täpsete konstruktsioonide osakaal & $79 \%$ & $89 \%$ & $75 \%$ & $87 \%$ \\
\hline Ebatäpsete konstruktsioonide arv & 19 & 15 & 9 & 16 \\
\hline $\begin{array}{l}\text { Ebatäpsete konstruktsioonide arv 1000 sõne } \\
\text { kohta }\end{array}$ & 0,8 & 0,7 & 0,4 & 0,7 \\
\hline Ebatäpsete konstruktsioonide osakaal & $21 \%$ & $11 \%$ & $25 \%$ & $13 \%$ \\
\hline
\end{tabular}

Verbi saama konstruktsioonide esinemissagedus kasvab B2-tasemel võrreldes B1-tasemega 1,6 korda ning konstruktsioonid muutuvad veidi täpsemaks. Verbi võima konstruktsioonide sagedus kasvab B1-tasemelt B2-tasemele liikudes koguni 3,9 korda ja konstruktsioonide täpsus kasvab rohkem kui saama-konstruktsioonide puhul. Kui võrrelda saama- ja võima-konstruktsioonide esinemissagedusi omavahel, on näha, et B1-tasemel on võima-konstruktsioonide esinemissagedus 2,5 korda madalam kui saama-konstruktsioonide sagedus. Samal ajal on B2-tasemel nende konstruktsioonide sagedused peaaegu võrdsed. Võib arvata, et kui saama-konstruktsioonid on B1-tasemel jõudnud oma arengu keskele ja seetõttu toimub nende edasine areng sujuvamalt, siis võima-konstruktsioonid 
on B1-tasemel veel üsna algusjärgus ja B2-tasemele liikudes toimub nende suur arenguhüpe.

\subsubsection{Sagedus tekstiliikide kaupa}

Lisaks üldisele sagedusele huvitas mind, kas vaatluse all olevate konstruktsioonide esinemissagedus sõltub tekstitüübist. Tabelites 2 ja 3 on esitatud saama-ja võimakonstruktsioonide esinemissagedused B1-tasemel ja B2-tasemel tekstitüüpide kaupa.

Tabel 2. B1-taseme saama-ja võima-konstruktsioonide esinemissagedus tekstitüüpide kaupa (absoluutarvud ja sagedus 1000 sõne kohta)

\begin{tabular}{|l|c|c|c|c|}
\hline Tekstitüüp & $\begin{array}{c}\text { saama B1 } \\
\text { (absoluutarv) }\end{array}$ & $\begin{array}{c}\text { saama B1 } \\
\text { (1000 sõne kohta) }\end{array}$ & $\begin{array}{c}\text { võima B1 } \\
\text { (absoluutarv) }\end{array}$ & $\begin{array}{c}\text { võima B1 } \\
\text { (1000 sõne kohta) }\end{array}$ \\
\hline Kirjad & 60 & 7,3 & 32 & 3,4 \\
\hline Jutud & 31 & 1,9 & 4 & 0,5 \\
\hline Kokku & 91 & & 36 & \\
\hline
\end{tabular}

Nii saama- kui ka võima-konstruktsioonid esinevad B1-tasemel kõigis tekstitüüpides, kuid kirjades (teadetes) tunduvalt sagedamini kui jutustavates tekstides. Saama-konstruktsioonide sagedus on kirjades (teadetes) 3,8 korda kõrgem kui jutustavates tekstides ja võima-konstruktsioonid on kirjades (teadetes) koguni 6,8 korda sagedasemad kui jutustavates tekstides. Seega on B1-tasemel mõlema, eriti aga võima-konstruktsiooni esinemine seotud tekstitüübiga.

Tabel 3. B2-taseme saama- ja võima-konstruktsioonide esinemissagedus tekstitüüpide kaupa (absoluutarvud ja sagedus 1000 sõne kohta)

\begin{tabular}{|l|c|c|c|c|}
\hline Tekstitüüp & $\begin{array}{c}\text { saama B2 } \\
\text { (absoluutarv) }\end{array}$ & $\begin{array}{c}\text { saama B2 } \\
\text { (1000 sõne kohta) }\end{array}$ & $\begin{array}{c}\text { võima B2 } \\
\text { (absoluutarv) }\end{array}$ & $\begin{array}{c}\text { võima B2 } \\
\text { (1000 sõne kohta) }\end{array}$ \\
\hline Kirjad & 61 & 6,4 & 67 & 7,1 \\
\hline Kokkuvõtted & 66 & 6,2 & 51 & 4,8 \\
\hline Esseed & 6 & 3,4 & 9 & 5,2 \\
\hline Kokku & 133 & & 127 & \\
\hline
\end{tabular}

Saama-konstruktsioone esineb B2-tasemel kõigis tekstitüüpides: sagedamini ametlikumat tüüpi tekstides (poolametlikud kirjad ja kokkuvõtted), neist ligikaudu kaks korda harvem esseedes. Võima-konstruktsioone esineb samuti kõigis tekstitüüpides: kokkuvõtetes ja esseedes enam-vähem võrdse sagedusega, neist ligikaudu 1,5 korda sagedamini poolametlikes kirjades. B2-tasemel ei ole kummagi verbi kasutus tekstitüübiga nii tugevalt seotud kui B1-tasemel. Võib oletada, et konstruktsioonid ilmuvad õppijakeelde kõigepealt prototüüpsemates, konkreetsema sisuga tekstitüüpides (nt saama-ja võima-konstruktsioonid B1-taseme kirjades, milles neid on sageli vaja kasutada, et sõnumit täpselt edastada) ja seejärel levivad ka muudesse tekstitüüpidesse (nt võima-konstruktsioonid B2-taseme esseedesse abstraktsemate mõttekäikude väljendamiseks). 


\subsection{Modaalverbide saama ja võima konstruktsioonide täpsus}

Järgnevalt vaatlen lähemalt ebatäpsete konstruktsioonide tüüpe.

Verbi saama konstruktsioonidest on B1-tasemel 79\% täpsed ja 21\% ebatäpsed. Ebatäpsuste hulgas on mõned juhud, kus emakeelne kõneleja kasutaks saama asemel suure tõenäosusega teist modaalverbi (nt tohtima, suutma) või mõnd muud modaalsuse väljendamise võimalust (1) või kus emakeelne kõneleja modaalsust üldse ei väljendaks (2).

(1) *Lapsed ei saa nii palju unistada. (B1)

(Lapsed ei tohiks nii palju unistada. Lastel ei ole kasulik nii palju unistada.) ${ }^{1}$

(2) *Kaase te saate võtta hea tuju ja optimism. (B1)

(Kaasa võtke hea tuju ja optimism.)

Lisaks esinevad B1-tasemel juhud, kus verbi saama on kasutatud vales morfoloogilises vormis, $d a$-infinitiivi asemel on kasutatud $m a$-infinitiivi, infinitiivivormis verb on sisuliselt ebasobiv või vale kirjapildiga.

B2-tasemel on saama-konstruktsioonide täpsus tõusnud. Ebatäpsused on seotud verbi saama vale morfoloogilise vormiga, ma-infinitiivi kasutamisega, infiniitse verbi ebasobiva valikuga.

Verbi võima konstruktsioonid on B1-tasemel pisut ebatäpsemad kui saamakonstruktsioonid, ebatäpsusi esineb veerandis kasutusjuhtudest. Seejuures on vaid mõned juhud seotud verbi võima sisuliselt ebatäpse tarvitamisega (3).

(3) *Kui sa võid kontserdile minna, siis helista mulle telefoninumbrile .. (B1) (Kui sa saad kontserdile tulla, siis helista mulle telefoninumbrile ..)

Ülejäänud ebatäpsused on seotud vale aja või kõneviisi kasutusega, infiniitse verbi vale valiku või ebatäpse kirjapildiga.

B2-tasemel on võima-konstruktsioonide täpsus tõusnud, ebatäpsusi esineb $13 \%$ juhtudest. Sisuliselt ebasobivalt on verbi võima seejuures kasutatud mõnel üksikul korral (4).

(4) *Selles olukorras sõbrad või vanemad ei või aidata temale. (B2) (Selles olukorras sõbrad või vanemad ei saa teda aidata.)

Lisaks on ebatäpsused seotud vale kõneviisi valikuga, ma-infinitiivi kasutamisega, sisuliselt ebasobiva verbi kasutamisega või verbi puudumisega, laiendiks oleva verbi kasutamisega mitteinfiniitses vormis või vale kirjapildiga.

Seega võib öelda, et nii saama-kui ka võima-konstruktsioonid on kõrge täpsusega juba B1-tasemel ja B2-tasemel nende täpsus tõuseb veel veidi. Huvitav on, et võima-konstruktsioonide sageduse märgatav tõus B2-tasemel ei too kaasa täpsuse langust. Et ebatäpsused on harva seotud modaalverbide sisuliselt ebakorrektse kasutusega, võib oletada, et kirjutajad kasutavad neid konstruktsioone rohkem meeldejäänud valmiskujul kui ise produktiivselt luues.

Autori moodustatud emakeelekõneleja laused on näidetele sulgudes lisatud. 


\subsection{Modaalverbide saama ja võima konstruktsioonide jaotuvus}

Lisaks sagedusele ja täpsusele on kostruktsioonide arengu täpsemaks kirjeldamiseks oluline vaadelda nende jaotuvust (mudelis DEMfad näitaja $d$ ). Kirjeldan saama- ja võima-konstruktsioonide morfoloogilist jaotuvust (5·3.1), süntaktilist jaotuvust $(5 \cdot 3 \cdot 2)$ ja funktsionaalset jaotuvust $(5 \cdot 3 \cdot 3)$.

\subsubsection{Morfoloogiline jaotuvus}

Kõigepealt vaatlen verbide saama ja võima vormide morfoloogilist jaotuvust kõneviiside ja aegade järgi (tabel 4 ).

Tabel 4. Verbide saama ja võima vormide jaotuvus kõneviisi- ja ajakategooria järgi (absoluutarvud ja osakaalud sama verbi vastava taseme kogujuhtudest)

\begin{tabular}{|l|c|c|c|c|}
\hline Vorm & saama B1 & saama B2 & võima B1 & võima B2 \\
\hline Kindla kõneviisi olevik (absoluutarv) & 76 & 128 & 33 & 108 \\
\hline Kindla kõneviisi olevik (osakaal) & $83 \%$ & $96 \%$ & $92 \%$ & $85 \%$ \\
\hline Kindla kõneviisi lihtminevik (absoluutarv) & 10 & 4 & - & 2 \\
\hline Kindla kõneviisi lihtminevik (osakaal) & $11 \%$ & $3 \%$ & - & $2 \%$ \\
\hline Tingiva kõneviisi olevik (absoluutarv) & 5 & 1 & 3 & 17 \\
\hline Tingiva kõneviisi olevik (osakaal) & $5 \%$ & $1 \%$ & $8 \%$ & $13 \%$ \\
\hline Kokku (absoluutarv) & 91 & 133 & 36 & 127 \\
\hline
\end{tabular}

Verb saama esineb nii B1- kui ka B2-tasemel peamiselt kindla kõneviisi olevikuvormides, eriti B2-tasemel. B1-tasemel esineb mõnevõrra ka kindla kõneviisi lihtminevikuvorme (siinkohal võib üheks mõjuriks pidada B1-taseme üht ülesandetüüpi, milles on sageli palutud kirjeldada mõnd minevikus toimunud sündmust) ja tingiva kõneviisi vorme.

Ka võima puhul domineerivad kummalgi tasemel kindla kõneviisi olevikuvormid, kuid erinevalt verbist saama on võima vormide sagedus B2-tasemel langenud. Seevastu on märgatav tingiva kõneviisi vormide sageduse mõningane tõus B2-tasemel.

Jälgisin ka eri pöördevormide (kuus jaatavat isikuvormi ja eitav vorm) esinemist igas kõneviisi ja aja kombinatsioonis (tabel 5).

Tabel 5. Verbide saama ja võima eri pöördevormide hulk (absoluutarvudes)

\begin{tabular}{|l|c|c|c|c|}
\hline Kõneviis ja aeg & saama B1 & saama B2 & võima B1 & võima B2 \\
\hline Kindla kõneviisi olevik & 7 & 7 & 5 & 7 \\
\hline Kindla kõneviisi lihtminevik & 5 & 2 & - & 1 \\
\hline Tingiva kõneviisi olevik & 3 & 1 & 2 & 7 \\
\hline Kokku & 15 & 10 & 7 & 15 \\
\hline
\end{tabular}

Verb saama esineb kummalgi tasemel kõigis kindla kõneviisi olevikuvormides ning B1-tasemel ka viies lihtminevikuvormis. Ülejäänud vorme esineb vähem. Verb võima esineb B1-tasemel viies kindla kõneviisi olevikuvormis ning vaid kahes tingiva 
kõneviisi vormis. B2-tasemel esinevad aga kõik kindla kõneviisi olevikuvormid ja ka kõik tingiva kõneviisi vormid. Seega on verbi võima puhul eri morfoloogiliste vormide esinemises toimunud B1-tasemelt B2-tasemele liikudes märgatav areng.

\subsubsection{Süntaktiline jaotuvus}

Järgmisena vaatlesin saama- ja võima-konstruktsioonide süntaktilist jaotuvust. Seejuures vaatlesin konstruktsiooni laiemalt kui vaid saama või võima koos nende juurde kuuluva ühe, peamise sõnaga (milleks on peaaegu alati verb infinitiivivormis). Jälgisin ka seda, kuidas sellised konstruktsioonid edasi laienevad.

Tabelis 6 on esitatud verbi saama konstruktsioonide süntaktiline jaotuvus.

Tabel 6. Saama-konstruktsioonide süntaktiline jaotuvus (absoluutarv ja osakaal sama verbi vastava taseme konstruktsioonidest)

\begin{tabular}{|l|c|c|c|c|}
\hline saama + & $\begin{array}{c}\text { B1 } \\
\text { (absoluutarv) }\end{array}$ & $\begin{array}{c}\text { B1 } \\
\text { (osakaal) }\end{array}$ & $\begin{array}{c}\text { B2 } \\
\text { (absoluutarv) }\end{array}$ & $\begin{array}{c}\text { B2 } \\
\text { (osakaal) }\end{array}$ \\
\hline Laienditeta & 5 & $5 \%$ & 4 & $3 \%$ \\
\hline$+\mathrm{V}_{\text {inf }}$ & 29 & $32 \%$ & 9 & $7 \%$ \\
\hline$+\mathrm{V}_{\text {inf }}+\mathrm{S}_{\text {nom/gen/part (sihitis, öeldistäide) }}$ & 19 & $21 \%$ & 54 & $41 \%$ \\
\hline$+\mathrm{V}_{\text {inf }}+\mathrm{S}_{\text {käänded/kaassõnad (määrus) }}$ & 32 & $35 \%$ & 56 & $42 \%$ \\
\hline$+\mathrm{V}_{\text {inf }}+$ adverb & 3 & $3 \%$ & 3 & $2 \%$ \\
\hline$+\mathrm{V}_{\text {inf }}+$ kõrvallause & 3 & $3 \%$ & 7 & $5 \%$ \\
\hline Kokku & 91 & & 133 & \\
\hline
\end{tabular}

Nii B1- kui ka B2-tasemel esinevad sama tüüpi süntaktilised konstruktsioonid, kuid nende osakaalud erinevad. B1-tasemel esinevad konstruktsioonid kolmandikul juhtudest ilma edasiste laienditeta $\left(+V_{\text {inf }}\right.$, näide 5$)$. B2-tasemel on selliste konstruktsioonide osakaal tunduvalt vähenenud.

(5) Kui sul ei ole raha, ma saan laenata. (B1)

Seevastu on B2-tasemel poole võrra tõusnud nominatiivis, genitiivis või partitiivis olevat substantiivi (valdavalt sihitist) sisaldava laiendiga konstruktsioonide hulk

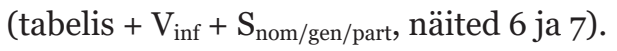

(6) Kui sul on vaba aeg, siis ma saan pakkuda pilet, sest minule ühel tuttaval jäi nüüd üks pilet. (B1)

(7) Seaduse järgi üks kord aastas, saab kasutada 3 lastepäevad ja nad on tasutud. (B2)

Sihitist sisaldavate konstruktsioonide hulgas võib märgata ka nende pikenemist B2-tasemel: tõusnud on nende konstruktsioonide hulk, mis sisaldavad veel mõnd laiendit (8).

(8) Ja ma tahan aru saada, kuidas ma saan sõlmida lepinguid internetis? (B2)

Kummalgi tasemel on suur osakaal konstruktsioonidel $+V_{\text {inf }}+S_{\text {käänded/kaassõnad (määrus) }}$ $(9,10)$. 
(9) Edaspidi sa saad mulle helistada või kirjutada e-mailile. (B1)

(10) Minu jaoks on tähtis mida ma söön ja ma ei saa lihast, kalast loobuda. (B2)

Kokkuvõttes võib öelda, et saama-konstruktsioonide peamine muutus B1-tasemelt B2-tasemele liikudes on konstruktsioonide pikenemine (neis esinevate liikmete lisandumine) ja sihitist sisaldavate konstruktsioonide osakaalu kasv.

Tabelis 7 on esitatud modaalverbi võima konstruktsioonide süntaktiline jaotuvus.

Tabel 7. Võima-konstruktsioonide süntaktiline jaotuvus (absoluutarv ja osakaal sama verbi vastava taseme konstruktsioonidest)

\begin{tabular}{|l|c|c|c|c|}
\hline võima + & $\begin{array}{c}\text { B1 } \\
\text { (absoluutarv) }\end{array}$ & $\begin{array}{c}\text { B1 } \\
\text { (osakaal) }\end{array}$ & $\begin{array}{c}\text { B2 } \\
\text { (absoluutarv) }\end{array}$ & $\begin{array}{c}\text { B2 } \\
\text { (osakaal) }\end{array}$ \\
\hline Laienditeta & - & - & 2 & $2 \%$ \\
\hline$+\mathrm{V}_{\text {inf }}$ & 1 & $3 \%$ & 11 & $9 \%$ \\
\hline$+\mathrm{V}_{\text {inf }}+$ snom/gen/part (sihitis, öeldistäide) & 18 & $50 \%$ & 69 & $54 \%$ \\
\hline$+\mathrm{V}_{\text {inf }}+$ skäänded/kaassõnad (määrus) & 16 & $44 \%$ & 26 & $20 \%$ \\
\hline$+\mathrm{V}_{\text {inf }}+$ adverb & - & - & 6 & $5 \%$ \\
\hline$+\mathrm{V}_{\text {inf }}+$ kõrvallause & 1 & $3 \%$ & 10 & $8 \%$ \\
\hline$+\mathrm{V}_{\text {inf }}+\mathrm{V}_{\text {inf }}$ & - & - & 3 & $2 \%$ \\
\hline Kokku & 36 & & 127 & \\
\hline
\end{tabular}

Verbi võima konstruktsioonidest moodustavad nii B1- kui ka B2-tasemel poole nominatiivis, genitiivis või partitiivis olevat substantiivi (valdavalt sihitist) sisaldava laiendiga konstruktsioonid ( $+\mathrm{V}_{\text {inf }}+\mathrm{S}_{\text {nom/gen/part }}$ ). Nende hulgas esineb kummalgi tasemel nii neid, millesse rohkem laiendeid ei kuulu $(11,12)$, kui ka enamate laienditega juhte $(13,14)$. Viimaste sagedus on aga B2-tasemel märgatavalt tõusnud.

(11) Me võime mängida võrkpalli ja jalgpalli.(B1)

(12) Palun, lähme koos, võid ka oma sõpru kutsuda. (B2)

(13) Lisainfot võib saada telefonist ... (B1)

(14) Ja kust mina võin teada Teie firma täpsed andmed. (B2)

Lisaks ilmub B2-tasemel sihitist sisaldavatesse konstruktsioonidesse ka laiendeid, mida B1-tasemel pole, nt kõrvallause (15) ja veel üks infinitiiv (16).

(15) Selle andmete põhjal võime teha järeldust, et inimesed hakkavad rohkem mõelda oma tervisest. (B2)

(16) Arvan, et sa võiks teda paluda ennast asendada. (B2)

B2-tasemel kahaneb määruse rollis olevate substantiivset laiendit sisaldavate konst-

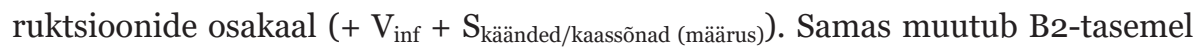
käänete kasutus abstraktsemaks. Näiteks kasutatakse B1-taseme kohakäändeid vaid konkreetse koha või liikumise väljendamiseks $(17,18)$, B2-tasemel aga ka kujundlikumas tähenduses $(19,20)$.

(17) Nüüd ma võin elada Ameerikas. (B1)

(18) Lisainfot võite saata minul, kirjutage minu mailile. (B1) 
(19) Siis mulle väga meeldis, et Teie kohvikus on lai valik erinevaid toite ja me võime valida midagi oma maitsele. (B2)

(20) Aga kui raha ei ole piisavalt, siis võib meelelahutustest loobuda. (B2)

B2-tasemel on tõusnud ka lühikese, ainult modaalverbi ja infinitiivi sisaldava konstruktsiooni $+\mathrm{V}_{\text {inf }}(21)$ ja kõrvallauset sisaldavate konstruktsioonide $\left(+\mathrm{V}_{\text {inf }}+\right.$ kõrvallause, näide 22) osakaal. B1-tasemel esineb kumbki neist konstruktsioonidest vaid korra.

(21) Kui tal ei õnnestu, siis pärast tagasi tulemist võime kokku leppida. (B2)

(22) Analüüsimiseks antud tabelist me võime aru saada kuidas inimesed eelistavad tervishoiu kohta infot saada. (B2)

B2-tasemel esinevad ka kolme tüüpi konstruktsioonid, mida B1-tasemel ei ole: ilma eksplitsiitse infinitiivita konstruktsioon (laienditeta, näide 23), adverbi ja seda täpsustavat kõrvallauset sisaldav konstruktsioon $\left(+V_{\text {inf }}+\right.$ adverb, näide 24) ja kahekordset infinitiivi sisaldav konstruktsioon $\left(+\mathrm{V}_{\text {inf }}+\mathrm{V}_{\text {inf }}\right.$, näide 25).

(23) Aga kaheksandal juunil küll võin mina. (B2)

(24) See võib põhjendada nii, et korteri eest on vaja maksta. (B2)

(25) Peale selle, ma pean leidma sponsoreid või huvitatuid isikuid, kes võiks aidata lahendada firma materiaalseid probleeme. (B2)

B2-tasemel on võima-konstruktsioonid seega muutunud pikemaks (lisandunud on neisse kuuluvaid liikmeid) ja kasvanud on nende tüüpide hulk.

\subsubsection{Funktsionaalne jaotuvus}

Siin vaatlen verbide saama ja võima konstruktsioonide jaotuvust suhtlusfunktsioonide kaupa. Suhtlusfunktsioonid on määratud artikli autori hinnangu järgi, arvestades vajaduse korral ka laiemat konteksti, milles konstruktsioon paikneb.

Tabelis 8 on toodud modaalverbi saama jaotuvus suhtlusfunktsioonide kaupa.

Tabel 8. Saama-konstruktsioonide funktsionaalne jaotuvus (absoluutarv ja osakaal sama verbi vastava taseme konstruktsioonidest)

\begin{tabular}{|l|c|c|c|c|}
\hline Funktsioon & $\begin{array}{c}\text { B1 } \\
\text { (absoluutarv) }\end{array}$ & $\begin{array}{c}\text { B1 } \\
\text { (osakaal) }\end{array}$ & $\begin{array}{c}\text { B2 } \\
\text { (absoluutarv) }\end{array}$ & $\begin{array}{c}\text { B2 } \\
\text { (osakaal) }\end{array}$ \\
\hline $\begin{array}{l}\text { Võime (osalejasisene dünaamiline } \\
\text { modaalsus) }\end{array}$ & 14 & $15 \%$ & 24 & $18 \%$ \\
\hline $\begin{array}{l}\text { Võimalus (osalejaväline } \\
\text { mittedeontiline modaalsus, } \\
\text { isikuline) }\end{array}$ & 63 & $69 \%$ & 92 & $69 \%$ \\
\hline $\begin{array}{l}\text { Võimalikkus (osalejaväline } \\
\text { mittedeontiline modaalsus, } \\
\text { üldisikuline) }\end{array}$ & 12 & $13 \%$ & 15 & $11 \%$ \\
\hline $\begin{array}{l}\text { Lubatus (osalejaväline deontiline } \\
\text { modaalsus) }\end{array}$ & 2 & $2 \%$ & - & - \\
\hline $\begin{array}{l}\text { Tõenäosus (episteemiline } \\
\text { modaalsus) }\end{array}$ & - & - & 2 & $1 \%$ \\
\hline Kokku & 91 & 133 & \\
\hline
\end{tabular}


B1- ja B2-tasemel on saama-konstruktsioonide funktsionaalne jaotuvus üsna sarnane. Kummalgi tasemel väljendatakse konstruktsioonidega peaaegu kolmveerandil juhtudest osalejavälist mittedeontilist modaalsust isikulises vormis $(26,27)$.

(26) Edaspidi sa saad mulle helistada või kirjutada e-mailile .. (B1)

(27) Ma tahaksin veel küsida, kas ma saan lepingut sõlmida teie kontoris? (B2)

Osalejavälise mittedeontilise üldisikulises vormis modaalsuse osakaal on kummalgi tasemel ligikaudu üks kümnendik $(28,29)$.

(28) Ürituse kohta saab vaadata internetis, näiteks "Facebook.com". (B1)

(29) Vaadates seda uuringu, saab rääkida, et vastanuid oli kokku 1500 inimest. (B2)

Osalejasisese dünaamilise modaalsuse osakaal B2-tasemel veidi kasvab (30, 31).

(30) Mina ei ole kirjanik, aga raamatute lugemisest saan kirjutada! (B1)

(31) Ma saan anda sulle kasuline nõu, mida sa võiks teha. (B2)

Kokkuvõttes võib öelda, et saama-konstruktsioonide funktsionaalses jaotuvuses ei toimu B1-tasemelt B2-tasemele liikudes märgatavat muutust.

Tabelis 9 on toodud modaalverbi võima jaotuvus suhtlusfunktsioonide kaupa.

Tabel 9. Võima-konstruktsioonide funktsionaalne jaotuvus (absoluutarv ja osakaal sama verbi vastava taseme konstruktsioonidest)

\begin{tabular}{|l|c|c|c|c|}
\hline Funktsioon & $\begin{array}{c}\text { B1 } \\
\text { (absoluutarv) }\end{array}$ & $\begin{array}{c}\text { B1 } \\
\text { (osakaal) }\end{array}$ & $\begin{array}{c}\text { B2 } \\
\text { (absoluutarv) }\end{array}$ & $\begin{array}{c}\text { B2 } \\
\text { (osakaal) }\end{array}$ \\
\hline $\begin{array}{l}\text { Võimalikkus (osalejaväline } \\
\text { mittedeontiline modaalsus) }\end{array}$ & 31 & $86 \%$ & 72 & $57 \%$ \\
\hline $\begin{array}{l}\text { Lubatus (osalejaväline deontiline } \\
\text { modaalsus) }\end{array}$ & 1 & $3 \%$ & 3 & $2 \%$ \\
\hline $\begin{array}{l}\text { Võime (osalejasisene dünaamiline } \\
\text { modaalsus) }\end{array}$ & 3 & $8 \%$ & 10 & $8 \%$ \\
\hline $\begin{array}{l}\text { Tõenäosus (episteemiline } \\
\text { modaalsus) }\end{array}$ & - & - & 17 & $13 \%$ \\
\hline $\begin{array}{l}\text { Põhjendatus (osalejaväline } \\
\text { mittedeontiline modaalsus, } \\
\text { olukorrast tingitud põhjendatus) }\end{array}$ & - & - & 17 & $13 \%$ \\
\hline $\begin{array}{l}\text { Soovitatavus (osalejaväline } \\
\text { mittedeontiline modaalsus) }\end{array}$ & 1 & $3 \%$ & 8 & $6 \%$ \\
\hline Kokku & 36 & & 127 & \\
\hline
\end{tabular}

B1-tasemel domineerib selgelt üks suhtlusfunktsioon: osalejaväline mittedeontiline modaalsus (32). Sama funktsiooni väljendamist esineb enim ka B2-tasemel (33), kuid ta osakaal on märgatavalt vähenenud.

(32) Edaspidi võite kontaktida mind telefoni teel, minu number on .. (B1)

(33) Kas te võiksite oma vastusega saata ka teie menüü, et me tutvusime sellega. (B2)

B2-tasemel on võrreldes B1-tasemega tõusnud osalejavälise mittedeontilise modaalsuse osakaal (34) ning episteemilise modaalsuse osakaal (35). 
(34) Ma võin põhjendada seda, et inimesed mõtlevad oma tervisest. (B2)

(35) Nad ei mõtle, mida võib oodata neid tulevikus. (B2)

Verbi võima funktsionaalne jaotuvus on seega B1-tasemelt B2-tasemele liikudes muutunud. B2-tasemel on vähenenud ühe, domineeriva suhtlusfunktsiooni osakaal, lisandunud on uusi funktsioone ning funktsioonide jaotuvus on muutunud mitmekesisemaks.

\section{Kokkuvõte}

Modaalverbi saama konstruktsioonide sagedus on B2-tasemel võrreldes B1-tasemega kasvanud poolteist korda. B1-tasemel on saama-konstruktsioonide kasutus seotud tekstitüübiga: valdavalt kasutatakse neid kirjades (teadetes), seevastu jutustavates tekstides esineb neid konstruktsioone harva. B2-tasemel ei ole saama- konstruktsioonid tekstitüübist nii suures sõltuvuses: kuigi vaadeldavad konstruktsioonid esinevad sagedamini poolametlikes kirjades ja kokkuvõtetes, on nende esinemissagedus ka arutlevates esseedes küllalt kõrge. Saama-konstruktsioonid on nii B1-tasemel kui ka B2-tasemel kõrge täpsusega, sisuliselt ebasobivat kasutust tuleb ette harva.

Morfoloogilise mitmekesisuse osas saama-konstruktsioonid B1-ja B2-taseme vahel ei arene. Eri morfoloogiliste tüüpide arv B2-tasemel väheneb võrreldes B1-tasemega. Süntaktilise jaotuvuse osas seevastu toimub B2-tasemele liikudes areng: saama-konstruktsioonid ei muutu küll süntaktiliselt mitmekesisemaks, kuid pikenevad (neisse lisandub rohkem liikmeid) ning kasvab sihitist sisaldavate konstruktsioonide osakaal. Funktsionaalselt saama-konstruktsioonide jaotuvus B1- ja B2-taseme vahel ei muutu. Kummalgi tasemel domineerib võrdse ülekaaluga osalejavälise mittedeontilise modaalsuse väljendamine.

Võima-konstruktsioonide sageduses toimub B1-tasemelt B2-tasemele liikudes suur hüpe: sagedus kasvab neli korda. B1-tasemel on võima-konstruktsioonid sarnaselt saama-konstruktsioonidega seotud tekstitüübiga, esinedes peamiselt kirjades (teadetes) ja tunduvalt harvemini jutustavates tekstides. B2-tasemel ei ole võimakonstruktsioonide kasutus enam nii tekstitüübiomane: kõige sagedasemad on nad poolametlikes kirjades, küllalt sageli esinevad aga ka esseedes ja algandmetele toetuvates kokkuvõtetes. Täpsus on võima-konstruktsioonidel B1-tasemel üsna kõrge (ebatäpseid kasutusjuhte on veerand), B2-tasemel tõuseb täpsus veelgi. Sisuliselt ebasobivaid võima kasutusi esineb kummalgi tasemel vähe.

Modaalverbi võima konstruktsioonid arenevad B1-tasemelt B2-tasemele liikudes ka jaotuvuse poolest: nii morfoloogiliselt, süntaktiliselt kui ka funktsionaalselt. Võima eri morfoloogiliste vormide arv kasvab B1-taseme seitsmelt B2-tasemel viieteistkümnele, eriti areneb seejuures tingiva kõneviisi eri vormide arv. Süntaktiliselt muutuvad verbi võima konstruktsioonid B2-tasemel pikemaks (neisse lisandub uusi liikmeid) ning mitmekesisemaks. Funktsionaalses jaotuvuses on B1-tasemelt B2-tasemele jõudes toimunud märgatav muutus. Kui B1-tasemel domineerib suure ülekaaluga üks suhtlusfunktsioon, osalejaväline mittedeontiline modaalsus, siis B2-tasemel on selle funktsiooni domineerivus selgelt vähenenud. Funktsionaalne jaotuvus on B2-tasemel muutunud mitmekesisemaks, lisandunud on kaks uut funktsiooni: tõenäosus (episteemiline modaalsus) ja põhjendatus (osalejaväline mittedeontiline modaalsus, olukorrast tingitud põhjendatus). 
Kokkuvõttes võib öelda, et nii saama-kui ka võima-konstruktsioonid arenevad B1-tasemelt B2-tasemele liikudes teise keele konstruktsioonide arengu üldistele põhimõtetele vastavalt. Modaalverb saama on ilmselt juba B1-tasemel jõudnud oma arengu keskele ning tema edasine areng on sujuvam. Modaalverbi võima konstruktsioonid on aga B1-tasemel alles oma arengu algusjärgus ning B1- ja B2-taseme vahel toimub nende arengus märgatav hüpe. B2-tasemel on oluliselt kasvanud võima-konstruktsioonide esinemissagedus, vähenenud nende tekstitüübiomasus ning kasvanud morfoloogiline, süntaktiline ja funktsionaalne mitmekesisus. Seega võib võima-konstruktsioonide arengut pidada üheks B1- ja B2-taset eristavaks indikaatoriks.

\section{Lühendid}

gen genitiiv

inf infinitiivivorm

nom nominatiiv

part partitiiv

S substantiiv

$\mathrm{V} \quad$ verb

\section{Viidatud kirjandus}

CEFR 2007 = Euroopa keeleõppe raamdokument. Õppimine, õpetamine ja hindamine. Tartu: Haridus- ja Teadusministeerium, 2007.

EKSS = Eesti keele seletav sõnaraamat I-VI. [The Explanatory Dictionary of Estonian.] Margit Langemets, Mai Tiits, Tiia Valdre, Leidi Veskis, Ülle Viks, Piret Voll (Toim.). Eesti Keele Instituut. Tallinn: Eesti Keele Sihtasutus, 2009. http://www.eki.ee/dict/ekss

Ellis, Nick C. 2002. Frequency effect in language processing. - Studies in Second Language Acquisition, 24 (2), 143-188. https://doi.org/10.1017/s0272263102002024

Erelt, Mati 2013. Eesti keele lauseõpetus. Sissejuhatus. Öeldis. [Estonian Syntax. Introduction. The predicate.] Tartu: Tartu Ülikool.

Eskildsen, Søren Wind 2008. Constructing a Second Language Inventory - The Accumulation of Linguistic Resources in L2 English. PhD dissertation. Institute of Language and Communication University of Southern Denmark. www.sdu.dk/ /media/CDD429BA88804790AED2582E82C6D302.ashx (17.10.2016).

Firth, Alan; Wagner, Johannes 1997. On discourse, communication, and (some) fundamental concepts in SLA research. - Modern Language Journal, 81 (3), 285-300. https://doi. org/10.1111/j.1540-4781.1997.tb05480.x

Goldberg, Adele 1995. Constructions. A Construction Grammar Approach to Argument Structure. Chicago: The University of Chicago Press.

Goldberg, Adele 2003. Constructions: A new theoretical approach to language. - Trends in Cognitive Sciences, 7 (5), 219-224.http://dx.doi.org/10.1016/S1364-6613(03)ooo80-9

Housen, Alex; Kuiken, Folkert; Vedder, Ineke 2012. Complexity, accuracy and fluency. Definitions, measurement and research. - A. Housen, F. Kuiken, I. Vedder (Eds.), Dimensions of L2 Performance and Proficiency. Complexity, Accuracy and Fluency in SLA. Amsterdam-Philadelphia: John Benjamins, 1-20. https://doi.org/10.1075/ lllt.32.01hou

Kitsnik, Mare 2015. Tingiv kõneviis eesti B1- ja B2-taseme kirjalikus õppijakeeles kui keeleoskuse arengu näitaja. [The conditional mood as an indicator of increased language competence in Estonian B1 and B2 level written learner language.] - Lähivõrdlusi. Lähivertailuja, 25, 137-171. https://doi.org/10.5128/LV25.06 
Kitsnik, Mare 2014. Verbivormid B1- ja B2-taseme kirjalikus õppijakeeles. [Written learner language verb forms at B1 and B2 levels.] - ESUKA / JEFUL, 5 (3), 9-35. http:// dx.doi.org/10.12697/jeful.2014.5.3.01

Langacker, Ronald W 2008. Cognitive Grammar: A Basic Introduction. Oxford: Oxford University Press. https://doi.org/10.1093/acprof:oso/9780195331967.001.0001

Larsen-Freeman, Diane 1997. Chaos/complexity science and second language acquisition. Applied Linguistics, 18 (2), 141-165. https://doi.org/10.1093/applin/18.2.141

Larsen-Freeman, Diane 2007. Reflecting on the Cognitive-Social Debate in Second Language Acquisition. - The Modern Language Journal, 91 (s1), 773-787. https://doi. org/10.1111/j.1540-4781.2007.00668.x

MacWhinney, Brian 2004. A unified model of language acquisition. - J. Kroll, A. de Groot (Eds.), Handbook of Bilingualism: Psycholinguistic Approaches. Oxford University Press, 49-67.

Martin, Maisa; Mustonen, Sanna; Reiman, Nina; Seilonen, Marja 2010. On becoming an idependent user. - I. Bartning, M. Martin, I. Vedder (Eds.), Communicative Proficiency and Linguistic Development: Intersections Between SLA and Language Testing Research. Eurosla Monographs Series 1. European Second Language Association, $57-80$.

Mustonen, Sanna 2015. Käytössä kehittyvä kieli. Paikat ja tilat suomi toisena kielenä oppijoiden teksteissä. [How Language Develops Through Use.] Jyväskylä Studies in Humanities 255. Jyväskylä: Jyväskylän yliopisto. http://urn.fi/URN:ISBN:978-951-39-6213-5

Reiman, Nina 2011. Two faces of complexity: Structural measures and diversity of constructions. - Nordland Nordisk tidsskrift for andersprakforskning, 6 (2), 9-33.

Seilonen, Marja 2013. Epäsuora henkilöön viittaaminen oppijansuomessa. [Indirect References in Finnish Learner Language.] Jyväskylä Studies in Humanities 197. Jyväskylä: Jyväskylän yliopisto. http://urn.fi/URN:ISBN:978-951-39-5025-5

Tragel, Ilona 2003. Eesti keele tuumverbid. [Estonain Core Verbs.] Dissertationes linguisticae Universitatis Tartuensis 3. Tartu: Tartu Ülikooli Kirjastus. http://hdl.handle. net/10062/41554

Verspoor, Marjolijn; Behrens, Heike 2011. Dynamic systems theory and usage-based approach to second language. - Marjolijn Verspoor, Kees de Bot, Wander Lowie (Eds.), A Dynamic Approach to Second Language Development: Methods and Techniques. Language Learning \& Language Teaching 29. John Benjamins, 25-38. http://dx.doi. org/10.1075/1llt.29.02ver

\section{Võrguviited}

Cefling = Linguistic Basis of the Common European Framework for L2 English and L2 Finnish. https://www.jyu.fi/hum/laitokset/kielet/tutkimus/hankkeet/paattyneet-hankkeet/ cefling/en (26.2.2017).

English Profile. http://www.englishprofile.org (17.10.2016).

EVKK = Eesti vahekeele korpus. [Estonian Interlanguage Corpus.] http://evkk.tlu.ee (17.10.2016).

SLATE $=$ Second Language Acquisition and Testing in Europe. http://www.slate.eu.org (17.10.2016).

Topling = Toisen kielen oppimisen polut. [Paths in Second Language Acquisition.] https:// www.jyu.fi/hum/laitokset/kielet/tutkimus/hankkeet/topling (17.10.2016). 
CONSTRUCTIONS WITH MODAL VERBS SAAMA

AND VÕIMA AS AN INDICATOR OF INCREASED

LANGUAGE COMPETENCE IN ESTONIAN

B1 AND B2 LEVEL WRITTEN LEARNER LANGUAGE

\section{Mare Kitsnik}

Tallinn University

The article describes the development of constructions with the modal verbs saama (can, may, be able) and võima (can, may, be able) in written exam texts of adult second language learners of Estonian at B1 and B2 level.

The study on which the article is based is part of a larger study, the goal of which is to develop linguistic descriptions to accompany the functional descriptions of B1 and B2 level given in the Common European Framework of Reference for Languages (CEFR 2007). This is to be achieved by identifying the linguistic categories typically used at these levels, describing and analyzing their frequency of use, accuracy and morphological, syntactical and functional distribution (Martin et al. 2010) and specifying descriptors that distinguish the levels.

The results of the study discussed in the article show that constructions with saama and võima both develop according to the general principles of learner language. The development of constructions with saama is smoother, but there is a big leap in the development of the constructions with võima between B1 and B2 levels. The frequency of constructions with võima is four times higher at the B2 level than at the B1 level, the dependency of these constructions on the text type is reduced, and the morphological, syntactical and functional distribution of the constructions shows a significant increase. The development of the constructions with the modal verb võima can be regarded as an indicator of B2 level.

Keywords: second language, language acquisition, frequency, accuracy, distribution, Estonian

\footnotetext{
Mare Kitsnik (Tallinna Ülikool) on eesti keele kui teise keele ekspert ning tegeleb keeleomandamise uurimise, metoodikaarenduse, õppematerjalide loomise, koolitamise, projektide koostamise ja juhtimise ning konsulteerimisega.

Narva mnt 29, 10120 Tallinn, Estonia

marekitsnik@gmail.com
} 